Chris Wright

\title{
The regulation of European labour mobility: National policy responses to the free movement of labour transition arrangements of recent EU enlargements
}

\begin{abstract}
This article analyses the reasons for the variation in policy responses of the older member states of the European Union with respect to the free movement of workers from the new member states that joined in 2004 and 2007. A combination of domestic political pressures and economic institutional factors, as well as the policy positions of other member states, can explain the differences in the policies adopted. Particular attention is paid to the UK, which was the only large EU-15 state to allow nationals from the eight states that joined the EU in 2004 to work freely in its labour market, but prevented Bulgarians and Romanians from being able to do so three years later.
\end{abstract}

Keywords: labour immigration, labour mobility, labour market regulation, European Union

Introduction

The principle of free movement of labour, which allows nationals from member states of the European Union (EU) to work without restriction in any other member state, is enshrined in the Treaty of Rome. However, when ten central and eastern Europe states joined the EU in 2004 and 2007, the fifteen existing western European member states of the EU ('the EU-15') were permitted to restrict nationals from the new member states from freely working in their labour markets for up to seven years. The stated rationale behind these measures was to protect EU-15 states against the prospect of increased unemployment, in the event of large inflows of workers from the poorer central and eastern European states. ${ }^{1}$ However, van Selm and Tsolakis assert that such measures were driven as much by:

Domestic political concerns in the context of slowing economies, high unemployment and antiimmigration sentiment. ${ }^{2}$

1 Christian Dustmann, Maria Casanova, Michael Fertig, Ian Preston and Christop M. Schmidt (2003) The impact of EU enlargement of migration flows Home Office Online Report 25/03, available at: www.homeoffice.gov.uk/rds/pdfs2/rdsolr2503.pdf [last accessed 10 March 2010].

2 Joanne van Selm and Eleni Tsolakis (2003) 'EU enlargement and the limits of freedom', Migration Information Source, 1 May, available at: 
Whatever the reason for their introduction, the transitional measures used by EU-15 states towards workers from the new EU members were mixed and varied. On the accession of the eight states that joined on 1 May 2004 - the Czech Republic, Estonia, Latvia, Lithuania, Hungary, Poland, Slovenia and Slovakia (the 'A8' states) - Ireland, Sweden and the United Kingdom were the only three EU-15 states to allow free movement from the outset. When the EU further enlarged three years later to include Bulgaria and Romania (the 'A2' states), only Sweden and Finland opened their labour markets from the date of accession.

This article analyses the reasons for the varied policy responses of EU-15 states to these two EU enlargements.

That member states adopted different transitional measures is perhaps not surprising. Different migration pressures, such as historical links with and geographical proximity to likely source countries, existing migrant communities, language and labour market dynamics, as well as varying capacities to accommodate increased populations, will make some destinations more attractive to prospective migrants than others, thus meaning that policies regulating the entry of immigrants will differ across states. ${ }^{3}$ Nonetheless, there are no obvious reasons for the varying responses of EU-15 states to the free movement provisions of the 2004 and 2007 enlargements.

Despite offering some important insights, previous studies that have highlighted the differing strategies used to combat far-right parties, or the protection of national welfare regimes, in explaining the varying policy responses of EU-15 states have lacked sufficient explanatory value. ${ }^{4}$ This article argues that a combination of domestic political pressures and economic institutional factors, as well as the policy positions of other member states, can explain the policies adopted by EU-15 states with respect to free movement for A8 and A2 nationals. Particular attention is paid to the case of the UK to illustrate this argument.

The UK is a curious case as it was the only large EU-15 state to allow A8 nationals to work freely in its labour market, but it subsequently prevented A2 nationals from being able to do so. Drawing on over forty interviews with UK government ministers, policy advisers, civil servants and lobbyists, as well as press reports and policy documents, the article examines the reasons for why the Blair government opted for a policy of free movement for workers from the new member states in 2004, but not in 2007. It argues that the Blair government allowed free movement for A8 workers because the economic case for doing so was stronger than in other EU-15 states, while the institutional strength provided by the UK state apparatus enabled the government to override the domestic political pressures which were opposed to such a policy. However, a lack

http://www.migrationinformation.org/Feature/display.cfm?ID=224 [last accessed 10 March 2010]. Emphasis in original.

3 Fraser Duncan and Steven Van Hecke (2008) 'Immigration and the transnational European centre-right: A common programmatic response?' Journal of European Public Policy 15: 435-436.

4 Katarzyna Gajewska (2003) 'Restrictions in labor free movement after the EU-enlargement 2004: Explaining variation among countries in the context of elites' strategies towards the radical right' Comparative European Politics 4: 379-398; Jon Kvist (2004) 'Does EU enlargement start a race to the bottom? Strategic interaction among EU member states in social policy' Journal of European Social Policy 14: 301-318. 
of political will - underscored by increased domestic opposition and fewer compelling economic reasons - deterred the Blair government from adopting free movement for A2 workers.

\section{Policy responses of EU member states to the 2004 enlargement}

The terms of the 2004 and 2007 enlargements of the EU - as agreed in the Treaties of Accession of 16 April 2003 and 25 April 2005 - specified that the existing EU member states were permitted to restrict the right of nationals from the A8 states acceding on 1 May 2004, and the A2 states acceding on 1 January 2007, to work freely in their labour markets for up to seven years. The Treaties established that the existing EU member states would be allowed to review their stances on the second and fifth anniversaries of the dates of accession. Similar transitional measures had been imposed when Greece, Spain and Portugal joined the European Economic Community in the $1980 s^{5}{ }^{5}$ In contrast to these earlier membership enlargements, when existing member states imposed similar labour market restrictions, ${ }^{6}$ the response of EU-15 states to the 2004 enlargement were mixed and varied. Belgium, Finland, Germany, Greece, France, Luxembourg and Spain adopted restrictive policies whereby essentially no or very limited scope was provided for A8 nationals to work; Austria, Denmark, Italy, the Netherlands and Portugal introduced quotas or work permit schemes for A8 nationals, often to work in specific or shortage sectors; while Ireland, Sweden and the UK allowed unrestricted access, although Ireland and the UK did impose restrictions on welfare provision. A number of the states that imposed restrictions subsequently removed them after the second anniversary of accession, either in part or in entirety. ${ }^{7}$ These contrasting policy positions were the products of strategic interactions between the EU-15 and their institutional state structures, as well as of domestic political pressures and structural economic factors.

\section{Strategic interactions between member states}

Kvist demonstrates that a number of states adopted their respective policy stances in reaction to those taken by other states, a process he terms 'strategic interaction'. The likely terms of accession for the 2004 enlargement had become apparent by late 2002. At that stage, Denmark, Greece, Ireland, the Netherlands, Sweden and the United Kingdom indicated that they would permit free movement, while the remaining EU-15 states suggested they would impose restrictions of varying degrees. ${ }^{9}$

5 Elena Jileva (2002) 'Visa and free movement of labour: The uneven imposition of the EU acquis on the accession states' Journal of Ethnic and Migration Studies 28, p. 691.

6 Tito Boeri and Herbert Brücker (2005) 'Why are Europeans so tough on migrants?' Economic Policy 20, p. 637.

7 Boeri and Brücker op. cit. p. 638; Gajewska op. cit. p. 380.

8 Kvist op. cit.

9 Stephen Castle (2002) 'UK lifts bar on workers from new EU countries' The Independent 11 December, p. 12; Anatole Kaletsky (2002) 'Why Britain needs more people like me' The Times 12 December, p. 22; Kvist op. cit. p. 311. 
Of those in the latter category, Germany and Austria, both states being the instigators behind the allowance by the European Commission (EC) for member states to use transitional measures, were the most vocal. The German and Austrian governments had successfully persuaded the EC that their shared borders and close economic, historical and cultural ties with a number of the accession states meant they would be the most likely destinations for A8 nationals, which their labour markets would struggle to accommodate. ${ }^{10}$ In fact, there were many A 8 nationals already working in Germany and Austria prior to accession, partly the result of bilateral agreements established after the fall of the Iron Curtain to fill labour shortages, particularly for low-wage and seasonal occupations in the construction, service and agricultural sectors. ${ }^{11}$ Table 1 shows the high numbers of A8 nationals living in Austria and Germany prior to the 2004 enlargement, both in absolute terms and relative to other EU-15 states. Moreover, a 2001 report on behalf of the EC, which factored in:

The impact of the wage differential, employment rates and some institutional factors

on migratory movements, had predicted around $335000 \mathrm{~A} 8$ and A2 nationals would move to the EU-15 within twelve months of accession, around 65 per cent of which would go to Germany and some 12 per cent to Austria. ${ }^{12}$

Table 1 - Stock of A8 nationals resident in the EU-15 member states prior to accession (most recent year)

\begin{tabular}{|l|c|c|c|c|}
\hline EU-15 member state & Year & Persons & $\begin{array}{c}\text { \% of national } \\
\text { population }\end{array}$ & $\begin{array}{c}\text { \% of A8 } \\
\text { residents in } \\
\text { EU-15 }\end{array}$ \\
\hline Austria & 2001 & 56930 & 0.70 & 7.16 \\
\hline Belgium* & 2001 & 13208 & 0.13 & 1.66 \\
\hline Denmark & 2003 & 9551 & 0.18 & 1.20 \\
\hline Finland & 2001 & 12804 & 0.25 & 1.61 \\
\hline France* & 2001 & 25869 & 0.04 & 3.25 \\
\hline
\end{tabular}

10 Jileva op. cit. pp. 693-695.

11 Adrian Favell and Randall Hansen (2002) 'Markets against politics: Migration, EU enlargement and the idea of Europe' Journal of Ethnic and Migration Studies 28: 589-590; Georg Menz (2002) 'Patterns in EU labour immigration policy: National initiatives and European responses' Journal of Ethnic and Migration Studies 28: 734-737.

12 Tito Boeri, Herbert Brücker et al. (2001) The impact of eastern enlargement on employment and labour markets in the EU member states European Integration Consortium, available at: $\mathrm{http}$ ://europa.eu/rapid/pressReleasesAction.do?reference=DOC/00/11\&for-

mat $=$ HTML\&aged $=1 \&$ language $=$ EN\&guiLanguage $=$ en, pp. 126-127 [last accessed 10 March 2010]. A later follow-up study for the EC came to similar conclusions: see Patricia Alvarez-Plata, Herbert Brücker, Boriss Silivers and DIW Berlin (2003) Potential Migration from Central and Eastern Europe into the EU-15 - An Update Report for the European Commission (DG Employment and Social Affairs), pp. 44-46. 


\begin{tabular}{|l|c|c|c|c|}
\hline EU-15 member state & Year & Persons & $\begin{array}{c}\text { \% of national } \\
\text { population }\end{array}$ & $\begin{array}{c}\text { \% of A8 } \\
\text { residents in } \\
\text { EU-15 }\end{array}$ \\
\hline Germany & 2001 & 470892 & 0.57 & 59.24 \\
\hline Greece* & 2001 & 23671 & 0.22 & 2.98 \\
\hline Ireland* & 2001 & 235 & 0.01 & 0.03 \\
\hline Italy & 2002 & 38399 & 0.07 & 4.83 \\
\hline Luxembourg & 2003 & 1865 & 0.42 & 0.23 \\
\hline Netherlands & 2002 & 55591 & 0.35 & 6.99 \\
\hline Portugal* & 2001 & 963 & 0.01 & 0.12 \\
\hline Spain* & 2001 & 16249 & 0.04 & 2.04 \\
\hline Sweden & 2001 & 22868 & 0.26 & 2.88 \\
\hline United Kingdom* & 2001 & 45858 & 0.08 & 5.77 \\
\hline Total & & 794953 & 0.21 & 100.00 \\
\hline
\end{tabular}

* Figures for these states also include nationals from Bulgaria and Romania.

Source: Kvist, Jon (2004) 'Does EU enlargement start a race to the bottom? Strategic interaction among EU member states in social policy' Journal of European Social Policy 14(3): 308.

Boeri and Brücker support the notion that EU-15 states engaged in a process of strategic interaction in devising their policy positions, claiming that the early decisions of Austria and Germany to restrict access 'fuelled fears' among other member states that 'migration flows could be diverted' into their labour markets.

Decisions to apply transitional periods in individual member states were carefully reviewed by other EU members and affected decisions elsewhere. ${ }^{13}$

Indeed, in the months immediately leading up to the accession, a number of EU-15 states that had previously been committed to free movement changed their positions. Despite its advocacy for membership expansion when holding the EU Presidency in 2002, Denmark decided to revise its position in order to prevent 'unintended use of social security benefits' and 'undue pressure on wages'. The Greek and Dutch governments then followed suit, ${ }^{14}$ with the latter citing the reversals of other EU-15 states, as well as prospective labour market burdens, to justify introducing a system of work permits and quotas for A8 workers. The volte-face of the Netherlands in turn prompted

13 Boeri and Brücker (2005) op. cit., pp. 668-669.

14 Anthony Browne (2004) 'Only Britain and Ireland welcome eastern influx' The Times 28 January, p. 16. 
the Swedish government to review its earlier pledge. Prime Minister Goran Persson claimed his government:

Would be naïve if we didn't see the risks if we were to be the only country welcoming people from eastern Europe to work for peanuts and giving them access to our social benefits.

However, the minority government failed to get majority support from the Swedish legislative assembly to overturn its previous commitment and was thus forced to maintain provisions for free movement. ${ }^{15}$

The policy reversals of other EU-15 states forced the Blair government in the UK to reconsider its earlier pledge in support of free movement. The week after the Swedish government had sought to impose transitional measures, the Immigration Minister Beverley Hughes said the government would impose restrictions

If an influx of workers poses a real threat to UK jobs. ${ }^{16}$

In the light of calls from conservatives and sections of the tabloid press to follow the lead of other EU-15 states, Blair pondered introducing a work permit scheme for A8 nationals. ${ }^{17}$ A senior government official says that the decisions of the larger EU-15 economies to impose restrictions:

Certainly made some people nervous and we knew as a consequence that we would get more than we otherwise expected, but we still thought that it would be a good thing.

Indeed, another senior civil servant says that the government decided to maintain its pledge to free movement, despite the reversals of other states, 'because we thought it was the thing we wanted to do'. ${ }^{18}$

Ultimately, the government confirmed that A8 nationals would be allowed to work unrestricted in the UK but, in order to prevent the possibility of 'benefit tourism', access to welfare benefits was prohibited during the first twelve months of employment. Somerville claims the creation of the scheme was 'a knee-jerk reaction to tabloid pressure'; an assertion verified by various senior government officials, one of whom says it was 'put together on a wing and a prayer' ${ }^{19}$ In justifying the hastiness of the measures, Home Secretary David Blunkett told the House of Commons:

15 Boeri and Brücker (2005), op. cit. p. 637; Kvist op. cit. pp. 301-302, 310-312.

16 Matthew Hickley (2004) 'Labour u-turn on migrants from countries joining EU' Daily Mail 2 February.

17 Nigel Morris (2004) 'Blunkett backs labour influx as EU grows' The Independent 10 February, p. 15 ; interview with government official.

18 Interviews with government officials.

19 Will Somerville (2007) Immigration Under New Labour Bristol: Policy Press, p. 136; interviews with government officials. 
When we first set out our position, only those countries with high levels of unemployment were planning to introduce restrictions on work for accession nationals. Since then, other countries have changed their stance. It clearly makes sense for us to ensure that our approach does not leave us exposed'. ${ }^{20}$

The Blair government's stance had a strong bearing on the decision of the Irish government also to allow free labour movement, but with similar restrictions on access to welfare. ${ }^{21}$ This was not the first time, however, that Ireland had followed the lead of the UK on EU immigration policy matters, a trend largely due to difficulties in policing the border it shares with the UK. ${ }^{22}$

\section{Domestic state structures and political pressures}

The transitional measures imposed by other member states was thus a factor influencing the policy stances of various EU-15 states on the question of free movement. Another ingredient, which goes further in explaining why some states adopted greater restrictions than others, was state structure, which shaped the response of governments to domestic political pressure. Key to understanding why the Blair government was able to pursue a policy of free movement, vis-à-vis other EU-15 governments, is the strong nature of the UK state. This meant that political obstacles - be it opposition from other parties, organised interests or the broader public - were more easily surmounted in pursuing desired policy objectives. Schmidt and Westrup explain that the UK's:

Unitary institutional structures, combined with statist policy-making and adversarial majoritarian politics that made of the government an "elective dictatorship", also made the imposition of reforms relatively easy, so long as the government had ideas it wanted to implement and the will to do so. ${ }^{23}$

The first-past-the-post, majoritarian nature of parliamentary democracy in the UK makes it difficult for fringe parties to gain representation and rarely results in coalition governments. In the absence of a strong second chamber, governments face few barriers to implementing their legislative agendas. The divide between the Labour and Conservative parties over immigration issues has, at times, been rather stark, as was the

20 Hansard House of Commons Debates, Vol. 418 (23 February 2004), columns 23-24.

21 Jonathan Portes and Simon French (2005) The Impact of Free Movement of Workers from Central and Eastern Europe on the UK Labour Market: Early Evidence Working Paper No. 18, Leeds: Department for Work and Pensions, p. 3.

22 Georg Menz (2009) The Political Economy of Managed Migration: Nonstate Actors, Europeanization, and the Politics of Designing Migration Policies Oxford: Oxford University Press, p. 201.

23 Vivien A. Schmidt and Jonathan Westrup (2008) 'Taking the state seriously: Policy, polity, and the politics of ideas and discourse in political economy', paper prepared for presentation to the American Political Science Association, Boston, 28 August-1 September, p. 16. Emphasis added. 
case in 2004, ${ }^{24}$ but Conservative criticism of the governing Labour Party's position on free movement did not, therefore, diminish the Blair government's capacity to implement such a policy, save for the restrictions on welfare access.

Gajewska has emphasised the role of state structure in shaping the responses of EU-15 states to free movement, specifically arguing that those operating in federal systems were more accountable to localised concerns about immigration than those operating in unitary states. ${ }^{25}$ There is a degree of correlation in this respect - federal states such as Germany imposed restrictions, whereas unitary states such as the UK, Ireland and Sweden did not - but this does not necessarily imply causation. Looking further afield, a number of federal states, such the United States, Canada and Australia, have among the most liberal immigration policy legacies. However, Gajewska is correct in highlighting the importance of state structure in conditioning the resilience of governments against, or their susceptibility towards, localised domestic pressures. In this respect, the strength of its unitary state, rather than external pressures or interests, has tended to define the parameters of immigration policy in the UK. Statham argues that:

The strong British state executive power that is manifest in the institutional framework and policy approach is also strongly expressed in the public debates about immigration and asylum... The public understanding and subsequent mobilisation about immigration politics is shaped very much from the top-down. The nation state, and in particular the political elite actors, have the leading role in shaping the debate and defining the axis of conflict around which it is constructed. ${ }^{26}$

Indeed, according to those involved in policy deliberations - leaving aside the issue of welfare restrictions - the decision of the UK to allow free movement for A8 nationals was very much an initiative of executive government, not one made in response to interest group or broader public pressures. Blair himself had claimed that successive UK governments - both Labour and Conservative - had staunchly advocated EU membership for central and eastern European states. ${ }^{27}$ Various government officials and ministers claim that, in light of the energy invested in building support for enlargement, the views across Whitehall and around the Cabinet table were strongly informed by the possibility that the positive bilateral relations fostered with A8 states would be undermined if their nationals were not afforded the same rights as those from the EU-15. This was an argument forcefully promoted by Foreign Secretary Jack Straw

24 See Christina Boswell, Meng-Hsuan Chou and Julie Smith (2005) Reconciling Demand for Labour Migration with Public Concerns about Immigration: Germany and the United Kingdom London: Anglo-German Foundation for the Study of Industrial Society, pp. 20-21; see also Gajewska op. cit. p. 391.

25 Gajewska op. cit.

26 Paul Statham (2003) Public debates, claims-making and the visible extent of "Europeanisation" within British immigration and asylum politics: An empirical analysis, paper presented at ECPR symposium, Marburg, 19 September, p. 11.

27 Tony Blair (2004) 'How ten new members can help us change Europe' The Times 30 April, p. 24 . 
and supported by Blair and Home Secretary David Blunkett. ${ }^{28}$ It is not exactly clear why such relations were considered more important by the UK government than those of its EU-15 counterparts, particularly if Schimmelfennig's arguments are accepted:

Central and Eastern Europe is neither geographically close nor economically important to Britain. The early and strong British commitment to enlargement is generally attributed to the "europhobia" of the Conservative governments. It appears to have been based on the calculation that an extensive "widening" of the [European] Community would prevent its further "deepening" and might even dilute the achieved level of integration. ${ }^{29}$

Even so, the importance of diplomatic considerations becomes more apparent in the context of the economic motivation for allowing free movement which, again, was largely the consequence of executive action. The championing by UK governments of a widening rather than a deepening of the EU was not simply a product of schadenfreude; its leaders also saw the economic opportunities that would arise from an enlarged common market. ${ }^{30}$ When confirming the government's decision to allow free movement to the House of Commons in February 2004, David Blunkett said it was because:

The accession of new countries into the European Union opens up new opportunities for trade and labour market flexibility. ${ }^{31}$

The Treasury was particularly influential in promoting this view within the government, asserting that free movement would allow the economy to grow further without wage inflation. ${ }^{32}$ According to a senior business lobbyist:

The Treasury - and with the benefit of hindsight, rightly - were picking up ... that the labour market was tightening, that companies were beginning to struggle to get the labour they needed, and that to continue the flexible labour markets which Gordon Brown knew were pivotal to British economic success ... a new intervention was needed, that we would need labour from Eastern Europe. ${ }^{33}$

28 Interviews with government officials and government ministers.

29 Frank Schimmelfennig (2001) 'The community trap: Liberal norms, rhetorical action, and the eastern enlargement of the European Union International Organization 55, p. 53.

30 Vivien A. Schmidt (2006) 'Adapting to Europe: Is it harder for Britain?' British Journal of Politics and International Relations 8, p. 28; see also Gideon Rachman (2006) 'The death of enlargement' The Washington Quarterly 29: 51-56.

31 Hansard op. cit. columns 23-24.

32 Interviews with business official and government minister.

33 Interview with business official. 
One senior civil servant says that this logic extended beyond the Treasury across the government to translate into:

A general view that the British economy would grow faster with less inflation with this group [of A8 workers]'. ${ }^{34}$

The influence of state executive power was also evident in the pragmatic considerations that underpinned the decision. Earlier in the decade, the buoyancy of the UK labour market, combined with a restrictive immigration policy, resulted in high numbers of people entering and working illegally, overstaying their visas and falsely claiming asylum, which had created political problems for the government. Through its policy of 'managed migration', the Blair government sought - as it turned out, rather successfully - to minimise illegal immigration and false asylum claims by widening the scope for people legally to enter, settle and work in the UK by opening up various channels for labour migration. In this context, David Blunkett and the Home Office promoted the view that, if the government imposed restrictions on A8 nationals in a climate of a high demand for labour, it risked undermining its managed migration policy. ${ }^{35}$

Weaker state structures can explain why other EU-15 governments were more impressionable than the Blair government as regards the domestic pressures seeking restrictions against A8 free movement. Three types of domestic political pressure are relevant in this respect: party politics; interest groups; and sources of popular pressure, such as public opinion and press coverage. The role of opposition parties in thwarting the plans of the Swedish government to introduce transitional measures may be seen as a consequence of the consensus-based politics of numerous western European democracies. However, the reason why the Swedish government had reneged on its earlier commitment to free movement was due to pressure from the trade union movement, an influential interest group in Swedish politics. ${ }^{36}$ Despite the increasingly liberal attitudes of European trade unions on immigration policies in recent years, ${ }^{37}$ this trend did not bear out in a universal manner in 2004. Trade unions in states such as the UK and Ireland supported free movement, but unions voiced opposition in a number of other states - often citing concerns that it could increase unemployment, drive down wages and undermine collective bargaining. For instance, trade union pressure was a factor influencing the restrictions sought by governments not only in Sweden but also in Germany and Austria. ${ }^{38}$

Interview with government official.

Interviews with government officials.

Kvist op. cit. pp. 311-312.

See Leah Haus (2002) Unions, Immigration and Internationalization: New Challenges and Changing Coalitions in the United States and France New York: Palgrave Macmillan; Julie R. Watts (2000) An Unconventional Brotherhood: Union Support for Liberalized Immigration in Europe San Diego: Centre for Comparative Immigration Studies.

Jileva op. cit. p. 694; Torben Krings (2009) 'A race to the bottom? Trade unions, EU enlargement and the free movement of labour' European Journal of Industrial Relations 15: 55-63. 
The weakness of other EU-15 states compared with the UK was also seen in the influence of public and media hostility over government decisions on free movement. Boswell, Chou and Smith assert:

The nature of anti-immigrant sentiment will determine, at least in part, the sorts of constraints that policy makers will face in their attempts to liberalise labour migration. ${ }^{39}$

It is, therefore, no great surprise that public hostility was a factor influencing the decision of a number of EU-15 governments to impose restrictions. This was not the case, however, in the UK, where public opposition to free movement, augmented by hostility from prominent tabloid newspapers such as the Daily Mail and The Sun, had little influence. Figure 1 demonstrates that immigration and related issues became increasingly salient from the election of the Blair government to the period preceding enlargement. Nonetheless, a long-standing and strong tradition of Euro-scepticism, and similar levels of public hostility to states like Austria and Germany that unequivocally opted for transitional measures ${ }^{40}$ did not deter the Blair government's resolve in allowing A8 nationals to work freely in the UK.

Figure 1 - Respondents citing immigration and race relations as one of the three most important issues facing Britain today, April 1997 to April 2004 (\%) (selected months)

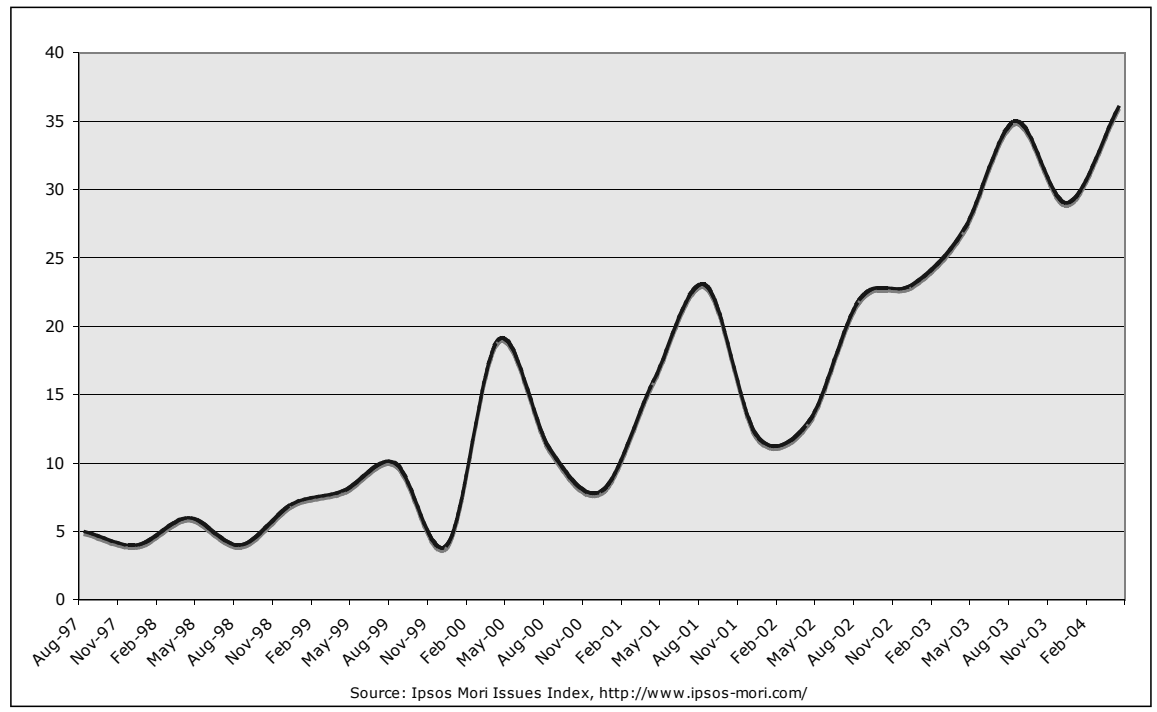

39 Boswell, Chou and Smith op. cit. p. 12.

40 Gajewska op. cit. p. 381. 


\section{Structural economic factors}

If the relative strength of the UK state better equipped the Blair government to override domestic political constraints so as to implement a policy of free movement, economic considerations were the primary motivations behind such a policy. It was seen above that there were multifarious considerations that prompted the UK government to open its labour market to A8 nationals from the date of accession, but the likely economic returns from such a policy were a fundamental factor. Labour shortages arising from low unemployment, fuelled by 15 years of sustained economic growth, meant that competition for jobs between A8 and UK residents was likely to be far less of a problem than in other EU-15 labour markets. ${ }^{41}$ However, most EU-15 governments saw free movement as having a potentially adverse economic impact whereas the Blair government saw the comparative advantages it could gain from opening its labour market to A8 nationals.

Government ministers justified the UK's response in terms of the prospective economic opportunities that would be delivered, similar to the way that both Labour and Conservative governments have championed labour market flexibility as a key component of the UK's comparative advantage. ${ }^{42}$ When announcing the Blair government's intention to allow A8 nationals to work freely in December 2002, Foreign Secretary Jack Straw said such a move was 'in the UK's interest' because it would 'attract workers we need in key sectors' ${ }^{43}$ In contrast, the language used by leaders of the EU-15 states that imposed restrictions was often couched in terms of the potential risks that would otherwise be posed to their more protectively regulated labour markets. For instance, German Chancellor Gerhard Schröder said that domestic labour markets, particularly those in areas bordering the accession states, would not be able to accommodate a large inflow of workers. ${ }^{44}$

This was also evident in the way that interest groups and the broader community responded to the prospect of free movement. Business groups and trade unions were hostile to such a position in states such as Germany and Austria whereas in the UK these groups were supportive. Public opinion and press coverage towards immigration was similarly ambivalent in the UK and Germany, but concerns about the labour market

41 This was also the case in Ireland, where the rates of employment growth and unemployment at the time of enlargement were the strongest in the EU. See Nicola Doyle (2007) 'The effects of Central European labor migration on Ireland' in Jen Smith-Bozek (Ed.) Labour Mobility in the European Union: New Members, New Challenges Washington DC: Center for European Policy Analysis, pp. 38-39.

42 See Karl-Orfeo Fioretos (1996) How and Why Institutional Advantages are Preserved in a Global Economy: A Comparison of British and Swedish Multilateral Preferences Discussion Paper FS 1 96-320, Berlin: Wissenschaftszentrum Berlin für Sozialforschung, p. 22; Martin Ruhs (2007) 'Greasing the wheels of the flexible labour market: East Central European labour immigration in the United Kingdom' in Jen Smith-Bozek (Ed.) op. cit. p. 9.

43 Stephen Castle (2002) 'UK lifts bar on workers from new EU countries' The Independent 11 December, p. 12.

44 Jileva op. cit. p. 694. 
impact were more apparent in the latter. ${ }^{45}$ This is consistent with the suggestion of Boeri and Brücker that:

Negative perceptions of migrants are larger in countries that have more generous social welfare systems and more "rigid" wage setting institutions. ${ }^{46}$

This was not simply a question of job vacancies and unemployment; there are also structural explanations for why free movement was a more appealing prospect in the UK rather than in other EU-15 states. Rates of unemployment and/or labour market inactivity were, in fact, lower in a number of other EU-15 states that adopted restrictive policies at the time of accession, such as Austria, Denmark, Luxembourg and the Netherlands, than they were in the UK. ${ }^{47}$ However, the more flexible nature of the UK labour market meant that it was better placed than other EU-15 states to absorb more workers without an accompanying increase in unemployment. ${ }^{48}$ Moreover, various 'system effects' of the UK's economic institutions had eroded the capacity of the government and employers to respond to labour shortages through orthodox strategies, such as increasing wages, investing in labour-saving technology or training resident workers. Anderson and Ruhs have argued that the UK was less equipped to respond to labour shortages than its EU-15 counterparts because the self-reinforcing nature of its lightly-regulated financial and labour market institutions meant that many employers were 'unable or unwilling to train' new staff, in part due to:

A fear of poaching, the rise of self-employment and the consequent importance attached to onthe-job training and learning by doing. ${ }^{49}$

Responses to the 2004 enlargement appear to be consistent with broader developments in the political economies of EU-15 states over the past few decades. Hall and Soskice have argued that the stance of nation states towards multilateral regulations will accord with whether such initiatives are:

45 Boswell, Chou and Smith op. cit. p. 27.

46 Boeri and Brücker (2005) op. cit. p. 662.

47 OECD (2005) Employment Outlook Paris: Organisation for Economic Cooperation and Development, pp. 237-239.

48 Will Somerville and Madeleine Sumption (2009a) Immigration and the labour market: Theory, evidence and policy Equality and Human Rights Commission/Migration Policy Institute, available at: http://www.migrationpolicy.org/pubs/Immigration-and-the-Labour-Market.pdf, p. 13 [last accessed 10 March].

49 Bridget Anderson and Martin Ruhs (2008) A need for migrant labour? The micro-level determinants of staff shortages and implications for a skills based immigration policy paper prepared for the Migration Advisory Committee, September, available at:

http://www.ukba.homeoffice.gov.uk/sitecontent/documents/aboutus/workingwithus/mac/ 239769/andersonandruhs2008, pp. 38-42 [last accessed 10 March 2010]; see also David Finegold and David Soskice (1988) 'The failure of training in Britain: Analysis and prescription’ Oxford Review of Economic Policy 4: 21-53. 
Likely to sustain or undermine the comparative institutional advantages of their nation's economy. ${ }^{50}$

Compared with its continental counterparts, the more liberal nature of its economic institutions helped the UK use the pressures of globalisation to its advantage, with its less regulated markets, low costs of production and flexible exchange rate attracting the foreign investment that enabled its economy to grow consistently over the decade preceding the global financial crisis. ${ }^{51}$ The decision of EU-15 states that imposed barriers to A8 nationals in the form of restrictions or quotas can, therefore, be interpreted as measures of protection consistent with the regulatory characteristics of their labour markets, whereas the UK's liberal stance was compatible with its more laissez-faire approach to market regulation.

The size of flows of A8 nationals to the UK and Swedish labour markets reinforces the explanatory importance of structural economic differences. Despite also adopting an open labour market policy with similarly low levels of unemployment - and, as noted above, more generous welfare provision for A8 nationals than offered by the UK - the inflow of A8 nationals into Sweden was much smaller. In the years after enlargement, over 200000 A8 nationals came to work in the UK each year, compared with over 120000 to Ireland, but only around 5000 to Sweden. ${ }^{52}$ Strong demand for labour in the UK and Ireland was one reason for these disparities, ${ }^{53}$ but weaker labour market regulation in both states enabled businesses to employ migrant workers on relatively lower wages and conditions, particularly compared with Sweden where much stronger regulation afforded no such scope. ${ }^{54}$

\section{Policy responses of EU member states to the 2007 enlargement}

When the membership of the EU was further enlarged on 1 January 2007 through the inclusion of Bulgaria and Romania, similar transitional arrangements applied with respect to the free movement of labour for nationals of the new member states. In contrast to their positions on the 2004 enlargement, the UK and Ireland restricted A2 nationals from freely working in their labour markets. The Blair government introduced annual quotas for some 20000 Romanians and Bulgarians to work, but only in lowskilled food processing and agricultural jobs, with self-employed workers exempt from

50 Peter A. Hall and David Soskice (2001) 'An introduction to varieties of capitalism' in Peter A. Hall and David Soskice (Eds.) Varieties of Capitalism: The Institutional Foundations of Comparative Advantage Oxford: Oxford University Press, p. 52.

51 Peter A. Hall (2007) 'The evolution of varieties of capitalism in Europe' in Bob Hancké, Martin Rhodes and Mark Thatcher (Eds.) Beyond Varieties of Capitalism: Conflict, Contradictions and Complementarities in the European Economy Oxford: Oxford University Press, pp. 66-67.

52 Catherine Drew and Dhananjayan Sriskandarajah (2007) 'EU enlargement in 2007: No warm welcome for labor migrants' Migration Information Source, 1 January 2007, available at: http://www.migrationinformation.org/feature/display.cfm?ID=568 [last accessed 10 March 2010].

53 Krings op. cit. p. 54

54 Ruhs op. cit. p. 24. 
restrictions. Finland and, again, Sweden were the only EU-15 states to adopt an open labour market policy from the date of accession, although they were also joined by a number of the states that had acceded in 2004: the Czech Republic; Cyprus; Estonia; Latvia; Lithuania; Poland; Slovenia; and Slovakia. However, as with the 2004 enlargement, a number of other member states fully or partly introduced free movement provisions after the second anniversary of the A2 accession. Drew and Sriskandarajah argue that the economies of Bulgaria and Romania were weaker than those of the A8 states and that:

The incentive to migrate toward higher wages could be greater.

Thus, the labour market and welfare concerns that had prompted many EU-15 states to introduce restrictions three years earlier were only more apparent on this occasion. These considerations were often:

Thinly veiled by justifications of consistent policy-making or diplomatic fairness. ${ }^{55}$

Given the UK's earlier position, however, such excuses were not available.

\section{The fallout from A8 enlargement and 'policy spillovers'}

In 2003, a report commissioned by the Home Office was published, indicating that the size of migration inflows to the UK would most likely be modest. Its authors estimated that the average annual net immigration to the UK from the new member states from the date of accession until 2010 would range from 5000 to 13000 people, but placed strong caveats on the validity of this estimation, saying that methodological shortcomings - particularly an absence of reliable statistics on net migration flows to the UK and from the A8 states - introduced 'a large potential error in the analysis'. This 'lack of good data' meant that the estimates were made 'using an entirely different set of sending countries'. The report concluded that:

Any study, no matter what approach it chooses, and on what data it is based, suffers from this serious caveat. ${ }^{56}$

55 Drew and Sriskandarajah op. cit.

56 According to the report, 'In the period after WWII, hardly any migration took place from the [A8 states] into Western Europe. This implies that studies which attempt to make predictions on the future migration from these countries have to use historical data on countries other than the [A8 states] in the estimation stage... [Therefore] one needs to assume that migration decisions will respond to the same factors in the same way as reflected by data on historical migration countries. Note that two assumptions are implicit here. First, an assumption of invariance across countries. Second, an assumption of invariance across time. The latter assumption means that future migrations react to changes in economic factors in the same way as past migrations. It is most unlikely that these assumptions hold'. See Dustmann et al, op. cit. pp. 29, 58 . 
This warning proved prophetic, as the scale of the inflows was significantly greater than the report anticipated. One year after the 2004 accession, some 200000 A8 nationals were recorded as working in the UK labour market and, by October 2006, this figure had increased to almost $500000 .{ }^{57}$ Ministers conceded that the scale of the inflow was 'unpredicted' 58

However, the Migration Advisory Committee (MAC) - an autonomous economic advisory body established by the government in 2007 - claims that the report's estimation of the total emigration flows of A8 workers was, in fact, correct. ${ }^{59}$ Where it erred was on the assumption that all EU-15 states would open their labour markets simultaneously; the possibility that there would be variation in the transitional arrangements adopted was not factored in. One of the authors later told a House of Lords committee inquiry that he was:

Absolutely sure that if Germany had opened its labour market to the accession countries we would have seen lower inflows to the UK. ${ }^{60}$

The experience over the 2004 enlargement made the Blair government much more wary of the 'policy spillovers' that could result from the decisions of other EU member states. When it later evaluated the UK government's restrictions on A2 workers, the MAC noted:

Perhaps the most relevant factor in determining the magnitude of immigration flows is also the most unpredictable: we cannot be certain what actions other EU countries will take in relation to the A2 restrictions ... If migrants' preferred destinations were fixed irrespective of restrictions, the impacts of other member states' decisions would be more limited. However, an important lesson from the 2004 accession is that preferences are partially constructed in relation to restrictions and opportunities in different countries. ${ }^{61}$

57 Border and Immigration Agency, the Department for Work and Pensions, HM Revenue \& Customs and the Office of the Deputy Prime Minister (2007) Accession Monitoring Report A8 Countries May 2004 - June 2007, available at:

http://www.homeoffice.gov.uk/about-us/non-personal-data/data-passports-immigration [last accessed 10 March 2010].

58 Liam Byrne (2007) “"Business isn't the only voice” - Key immigration reforms over the last 12 months' Minister of State for Immigration, Citizenship and Nationality, Speech to KPMG, London 4 June.

59 Migration Advisory Committee (2008) The labour market impact of relaxing restrictions on employment in the UK of nationals of Bulgarian and Romanian EU member states December 2008, available at:

http://www.ukba.homeoffice.gov.uk/sitecontent/documents/aboutus/workingwithus/mac/ a2-report/1208/relaxing-restrictions?view=Binary, 5.3-5.4 [last accessed 10 March 2010].

60 House of Lords Select Committee on Economic Affairs (2008) The Economic Impact of Immigration: Volume I-Report, 1st Report of Session 2007-08, London: The Stationery Office, p. 74 .

61 Migration Advisory Committee (2008) op. cit. 6.10-6.11. 
This uncertainty had a strong influence on the announcement by the Blair government in October 2006 to restrict labour market access to A2 workers. One senior civil servant comments that the magnitude of the error in predicting the inflow of A8 workers, combined with ambiguity over the positions of other EU-15 states, deterred the government from allowing free movement for Bulgarians and Romanians because:

We couldn't say on the second accession ... "Well, there won't be all that many, it will be fine". That [option] wasn't really open to us. ${ }^{62}$

\section{Domestic political pressures}

The significant media attention garnered by the erroneous predictions amplified the government's reservations for free movement for A2 workers, as it fuelled broader perceptions that the government had lost control of the UK's borders. This was not helped by scandals and ministerial resignations over other immigration issues earlier in 2006. ${ }^{63}$ A consequence of the unanticipated size of A8 inflows was that local public service providers were ill-equipped to accommodate new settlers that had not been planned for. In mid-2006, complaints surfaced from the Local Government Association that the influx had placed pressure on public services, hospitals and schools. ${ }^{64}$ The opposition Conservative Party echoed these concerns, ${ }^{65}$ as did a number of interest groups, including the media-savvy Migrationwatch UK - a self-styled think-tank that had been consistently critical of the Blair government's immigration policies - and various peak-level business organisations. The Director-General of the British Chambers of Commerce said that A8 workers had 'higher-level skills and a far better attitude to work than local people', but that their 'vast' number risked creating 'significant social problems'. He pondered whether 'enlargement fatigue' made it wise to impose working restrictions on A2 nationals. ${ }^{66}$ The Director-General of the Confederation of British Industry also claimed it would be a mistake to for the government to:

Throw open our doors to these new member states immediately... The question is about the numbers, the sheer numbers. This is by far the biggest wave of immigration in the history of these islands. It has implications for the social fabric, for housing and education, for the way we live in this country... We should have a pause for breath before the next wave of new comers. ${ }^{67}$

62 Interview with government official.

63 Drew and Sriskandarajah op. cit.

64 Robert Watts (2006) “"Migrants are more enthusiastic, more punctual and better prepared" Sunday Telegraph 27 August, p. 7.

65 Steven Swinford (2006) 'How many others can we squeeze in?' Sunday Times 27 August, p. 12; see also Julie Smith (2008) 'Towards consensus? Centre-right parties and immigration policy in the UK and Ireland' Journal of European Public Policy 15: 424.

66 Jean Eaglesham (2006) 'Business warns of migration diversion' Financial Times 24 July, p. 2.

67 Becky Barrow (2006) 'Britain needs a rest from immigration, warns new CBI chief' Daily Mail 6 September, p. 17; Larry Elliott (2006) 'Migrants threaten social fabric, says CBI chief' The Guardian 6 September, p. 21. 
Given the business community's support for the Blair government's previous liberal immigration initiatives, it is curious that peak-level business groups supported restrictions on Bulgarian and Romanian workers. One explanation offered for this response is the complaints from local businesses that the economic benefits from A8 immigration were not compensating for the 'social' costs. Added to this was a concern among business groups that the government had lost control of immigration. In the words of one business lobbyist:

The business mood shifted because the public mood shifted... The government had appeared to have lost control. It appeared that the government didn't have the faintest how many people were in the country. ${ }^{68}$

Opinion polling in the run-up to the government's decision reflected unease in the broader community. Figure 2 demonstrates that immigration became an even more salient policy issue throughout 2006, leading to the government announcement that September, coinciding with sustained press coverage of the increasing number of A8 workers entering the UK. Figure 3 shows that, in the month of the A2 decision, 'asylum and immigration' was the third most important issue shaping voting intention, while Figure 4 demonstrates that the issue was not clearly galvanising electoral support for the governing Labour Party.

Figure 2 - Respondents citing immigration and race relations as one of the three most important issues facing Britain today, April 2004 to August 2006 (\%) (selected months)

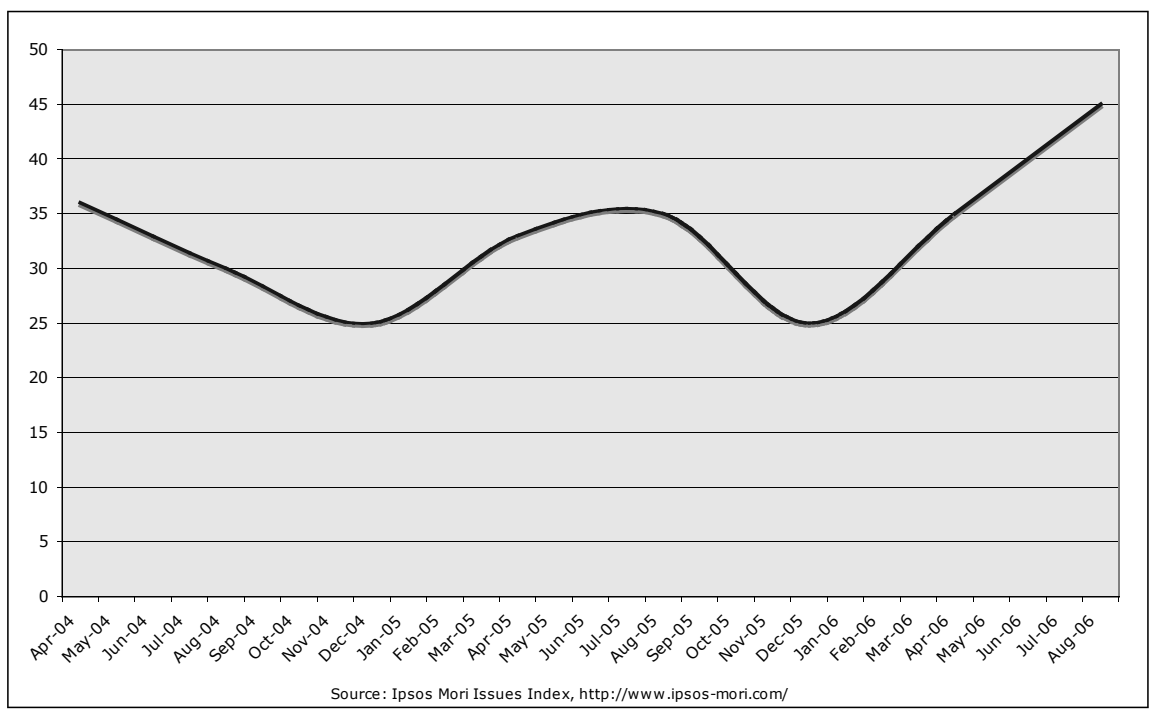


Figure 3 - Importance of key issues to in helping respondents decide which party they would vote for, September 2006 (\%)

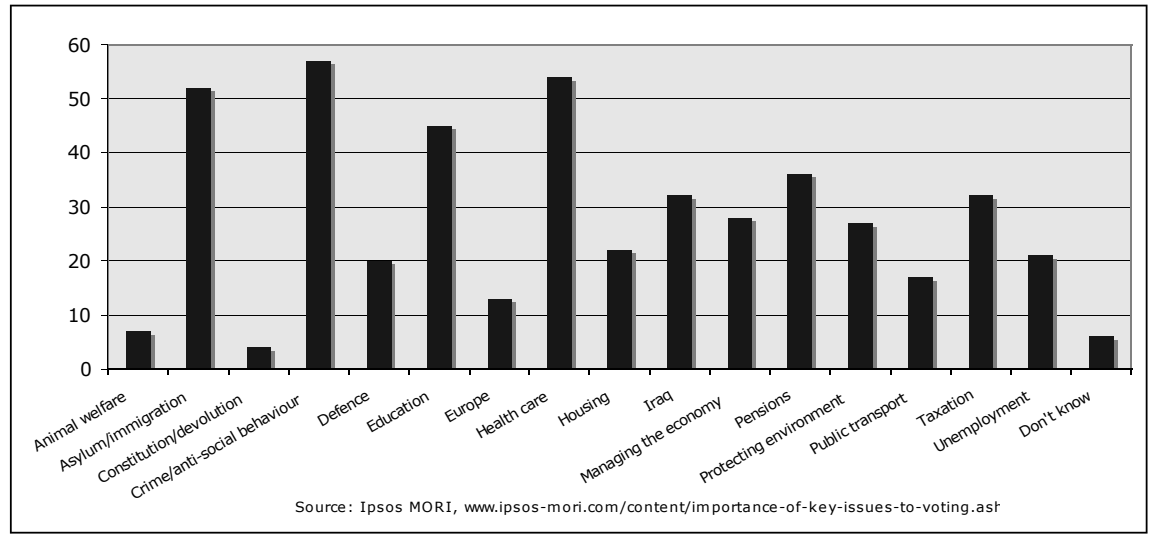

Figure 4-Respondents citing the party they believe has the best policies on asylum and immigration, September 2006

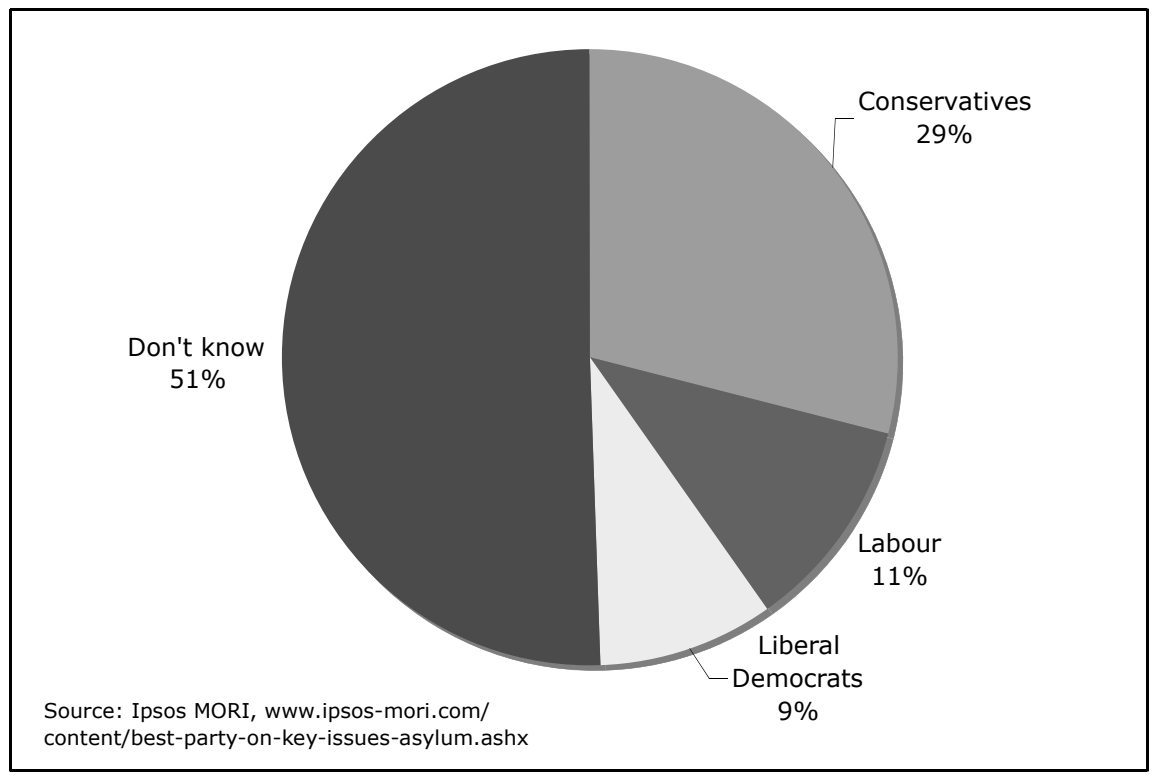

The disquiet among opposition parties, interest groups and the broader community about the unanticipated inflows of A8 workers and the impact on public services was 
a major factor in the government's decision to impose restrictions. ${ }^{69}$ In announcing the restrictions, Home Secretary John Reid acknowledged they were partly in response to such concerns. ${ }^{70}$

\section{Economic factors}

If the strength of the UK state had been able to withstand opposition to free movement in 2004, its inability to do so in the circumstance of the 2007 enlargement warrants explanation. There had been a solid economic case for granting A8 workers unfettered access to the UK labour market. Despite the size of the inflows, the impact of A8 workers on the UK economy and labour market was seen within the government as positive and a reason to consider continuing the policy of free movement. ${ }^{71}$ There was a view - supported by various studies both at the time and subsequently ${ }^{72}$ - that these workers were having little, if any, negative effects on the wages or employment prospects of UK residents and that, in any case, they were having a positive fiscal impact, contributing to growth and productivity and helping to fill labour and skills shortages across the economy. ${ }^{73}$

However, there was a view that the economic case for opening the labour market to A2 workers was not as compelling. According to one business lobbyist:

The economic cycle was different [with] the decision on A2 as against [A8]. Unemployment was going up, growth had slackened, the skill set of Romania and Bulgaria was not the same as the skill set of Poland, there was less use of the English language, a less traditional connection with the UK. So most of our members, particularly the ones interested in skilled labour, didn't see as big an opportunity with Romania and Bulgaria as they had with Poland and the Czech Republic. $^{74}$

Moreover, Drew and Sriskandarajah claim that, compared to their A8 counterparts, nationals from the A2 states were 'less favourably perceived' by policy-makers in Whitehall:

Publicly held beliefs about Bulgaria and Romania's inclinations toward organized crime and corruption were reinforced by the EU Commission's delay in confirming the 2007 accession date for those very reasons. ${ }^{75}$

69 Interviews with government officials.

70 Guardian Unlimited (2006) 'UK to limit EU entrants' working rights', 24 October; Nigel Morris and Jonathan Brown (2006) 'Reid accused of pandering to media pressure with curbs on immigrants' The Independent 25 October, p. 6.

71 Interviews with government officials.

72 See Nicholas Gilpin, Matthew Henty, Sarah Lemos, Jonathan Portes and Chris Bullen (2006) The Impact of Free Movement of Workers from Central and Eastern Europe on the UK Labour Market Working Paper No. 29, Leeds: Department for Work and Pensions, p. 1; Somerville and Sumption (2009a) op. cit. p. 14.

73 Migration Advisory Committee (2008) op. cit. para. 5.31.

74 Interview with business official.

75 Drew and Sriskandarajah op. cit. 
Despite the unfair and prejudicial connotations of these attitudes, they were indeed cited by ministers and senior civil servants as factors underpinning the government's decision to restrict free movement to A2 nationals. ${ }^{76}$ The government's political will to replicate its earlier position was thus diminished by the view that the economic advantages likely to be delivered by A2 workers were less clear-cut.

\section{Conclusion}

The UK government allowed free movement for workers from new EU member states in 2004 because the economic case was more apparent than in other EU-15 states, while the institutional strength of the state enabled it to over-ride domestic opposition to such a position. However, opposition was more widespread and vocal to the prospect of free movement when the EU further expanded. The institutional capacity of the UK state to abrogate such opposition was no weaker, but the economic benefits were less obvious than they had been three years earlier, thus moderating the government's political resolve. Political imperatives therefore overshadowed the economic imperatives that underpinned the A8 decision, but there appeared to be less at stake for the Blair government in terms of foreign policy considerations. The introduction of a more stringent system of border control and migration management in 2006 also meant that the pragmatic reasons for allowing free movement for A2 workers were not as strong as they had been for A8 ones in 2004.

However, one cannot overlook the importance of 'events' in shaping the course of policy; had the size of the A8 inflows been more consistent with expectations, the government may have had greater determination to grant free movement to Bulgarians and Romanians. It has indeed been shown that inaccurate information about the size of immigration flows is likely to amplify negative public attitudes. ${ }^{77}$ Moreover, Freeman points out that:

It is obvious, of course, that the politics of immigration in liberal democracies fluctuates, that its salience ebbs and flows, and that it exhibits a tendency to go through predictable cycles.

In the 'good times/bad times dynamic' of such cycles, periods of immigration expansion often precede popular backlash during which immigrants:

Are targeted as scapegoats for conditions they may have no part in causing. ${ }^{78}$

Despite evidence that A8 workers were making a positive economic contribution with minimal negative consequences, the emergence of vague concerns about the capacity of public services to cope should perhaps not be surprising, particularly given the longstanding sensitivity of immigration politics in the UK.

76 Interviews with government minister and government official.

77 John Sides and Jack Citrin (2007) 'European opinion about immigration: The role of identities, interests and information' British Journal of Political Science 37: 477-504.

78 Gary P. Freeman (1995) 'Models of immigration politics in liberal democratic states' International Migration Review 29: 886. 
The immigration politics of many other western European states came to be marked by sensitivity, division and restriction after they ended their guest worker programmes in the 1970s. A recent work by Adrian Favell notes the refreshing absence of such politics in relation to the generation of 'free movers' within western Europe that have become increasingly prevalent in recent years:

[While] Britain remains fixated on more "exotic" forms of cultural difference as a threat ... nobody notices or complains about the well-spoken French, Italian or German kids working in cafes, trains, hotel lobbies, or bargain airlines. They are unproblematic, and no politician or policy maker need ever make a fuss... They are also more often than not temporary and shortterm migrants, who will not be looking for childcare benefits, schools, medical treatment, or retirement care in the long run... The British economy gets an almost free ride on the back of the superior state school systems and cheaper universities of its neighbours. These well brought up, highly educated young Europeans come to Britain with degrees in hand only to work in snack bars and menial office jobs. They are motivated, dynamic, and ideal employees; but they are willing to take a cut in pay and quality of life, just to be in London. The city and the national economy pockets the difference'. ${ }^{79}$

These characteristics have been echoed in the appraisals by UK businesses of the central and eastern Europeans that came to work after $2004 .{ }^{80}$ Unfortunately, despite such praise, and despite the more enlightened position taken by the Blair government in 2004 compared with many of its EU-15 counterparts, the UK ended up returning to the old politics of immigration three years later. Drew and Sriskandarajah claim that:

The restrictive decisions of the majority of the EU-15 member states are reminders of the broader challenges of balancing free movement and national labour market protection. ${ }^{81}$

However, it appears that many nationals from the new EU member states did not go to the EU-15 states after 2004 as 'immigrants' seeking permanent settlement, but rather as circular free movers contributing to a new European economic dynamism. ${ }^{82}$ It has been estimated that around one-half of the roughly one million A8 nationals that arrived in the UK between 2004 and 2008 have subsequently departed for their home

79 Adrian Favell (2008) Eurostars and Eurocities: Free Movement and Mobility in an Integrating Europe Oxford: Blackwell, pp. 35-36.

80 See Bridget Anderson, Martin Ruhs, Ben Rogaly and Sarah Spencer (2006) Fair enough? Central and East European migrants in low-wage employment in the UK York: Joseph Rowntree Foundation.

81 Drew and Sriskandarajah op. cit.

82 Adrian Favell (2009) 'Immigration, migration and free movement in the making of Europe' in Jeffrey C. Checkel and Peter J. Katzenstein (Eds.) European Identity Cambridge: Cambridge University Press, pp. 167-189. 
countries or other destinations. ${ }^{83}$ Given that EU-15 states have to phase out all restrictions on A 8 workers by 2011 and on A 2 workers by 2014, they will be forced to regard these workers not as immigrants but as free movers. It can only be hoped that, with this transition, the old divisive politics of immigration is also left behind.

83 Naomi Pollard, Maria Latorre and Dhananjayan Sriskandarajah (2008) Floodgates or Turnstiles? Post-EU Enlargement Migration Flows to (and from) the UK London: Institute for Public Policy Research, p. 5. It should be noted that there is evidence that this trend has slowed since the onset of the global financial crisis. See Will Somerville and Madeleine Sumption (2009b) Immigration in the United Kingdom: The recession and beyond Equality and Human Rights Commission/Migration Policy Institute, available at: http://www.migrationpolicy.org/ pubs/Immigration-in-the-UK-The-Recession-and-Beyond.pdf, pp. 41-42 [last accessed 10 March 2010]. 